\title{
Ocena modernizacji lokomotywy SM 42 w aspekcie hałasu na stanowisku pracy maszynisty
}

\begin{abstract}
$W$ artykule przedstawiono wyniki badań dotyczqcych poziomu hałasu na stanowisku maszynisty w lokomotywach manewrowych serii SM42 podczas ich postoju (z właczonym silnikiem spalinowym). Porównano wyniki pomiarów hałasu w kabinach lokomotyw przed modernizacja, z wynikami pomiarów lokomotyw zmodernizowanych przez Zaktady Naprawcze: „PESA Bydgoszcz” oraz „NEWAG Nowy Sacz". Opisano zakres modernizacji lokomotyw SM 42 oraz przedstawiono najważniejsze akty prawne dotyczqce hałasu na stanowisku pracy.
\end{abstract}

\section{WPROWADZENIE}

Od chwili zaprzestania produkcji lokomotyw SM 42, nastapił bardzo powolny rozwój udoskonaleń technicznych. Pojazdy wykonujące setki tysięcy kilometrów pracy przewozowej były poddawane naprawie głównej, która nie wprowadzała istotnych zmian konstrukcyjnych dla poprawy osiagów technicznych i zmniejszenia narażenia zdrowia maszynistów. Powolny rozwój techniczny wynikał przede wszystkim ze zmiany systemu ustrojowego w Polsce, co skutkowało pojawieniem się braku nakładów finansowych na produkowanie nowych pojazdów.

Rozwiązania techniczne jakie zostały zaprojektowane w lokomotywach serii SM42 jak na przykład niewygodne siedziska maszynisty, powodowały wzrost liczby pracowników z chorobami układu kostnego i nerwowego. Nie podejmowano działań poprawiających warunki pracy maszynisty do czasu utworzenia, a w zasadzie reaktywacji niektórych Zakładów Naprawczych Taboru Kolejowego w Polsce. Po wstapieniu Polski do Unii Europejskiej rozpoczęto modernizację taboru kolejowego (dzięki projektom dofinansowań), w celu wyrównania standardów pomiędzy państwami, a co za tym idzie poprawie bezpieczeństwa, zmniejszenia negatywnych oddziaływań taboru na środowisko oraz zwiększenia komfortu pracy maszynisty. Warunki, w jakich pracuje maszynista bardzo istotnie wpływają na bezpieczeństwo zarówno jego, pasażerów w ruchu pasażerskim, jak i ładunków w ruchu towarowym. W związku z powyższym podjęto liczne prace nad modernizacjami lokomotyw, w tym omawianych w artykule spalinowych lokomotyw serii SM42.

\section{MODERNIZACJE LOKOMOTYW SERII SM42}

2.1. Modernizacja przez zakład „Pojazdy Szynowe PESA Bydgoszcz"
W zmodernizowanej lokomotywie serii SM42 (typ 6Dk) układ osi oraz przeznaczenie eksploatacyjne zostało zachowane jak w pierwotnej lokomotywie przed modernizacją. Producent nie wyposażył lokomotywy w możliwość ogrzewania pociagów pasażerskich, co w dalszym ciagu ogranicza wykorzystanie pojazdu w ruchu pasażerskim. Lokomotywie pozostawiono jedną kabinę maszynisty. Jedną z nowości, jaka została wprowadzona to umożliwienie pracy lokomotywy w trakcji wielokrotnej. Możliwe będzie, zatem prowadzenie dwóch lub więcej lokomotyw z jednej kabiny. Masa lokomotywy zwiększyła się o 2 tony. Nowe rozwiązanie konstrukcyjne, jakie zastosowano to umiejscowienie kabiny maszynisty w środkowej części ramy głównej. Symetrycznie po obu stronach kabiny zostały zabudowane dwa identyczne agregaty napędowe. Kabina maszynisty została całkowicie zmodyfikowana w typ tzw. wieżowy, do której z jednej strony przylega przedział pneumatyczny, $z$ drugiej przedział elektryczny. Agregat napędowy składa się z silnika spalinowego czterosuwowego typu C15 ACERT firmy Caterpillar, który napędza prądnice główną prądu przemiennego (AC - alternatingcurrent). Silniki trakcyjne lokomotywy nie zostały wymienione podczas modernizacji, zatem pracują $\mathrm{w}$ systemie prądu stałego (DC - directcurrent). W związku z tym, zainstalowany został układ prostowniczy) umożliwiający transformacje prądu AC na DC. Agregaty napędowe mają możliwość pracy równoczesnej, każdy dając zasilanie na dwa silniki trakcyjne lub moga pracować osobno, zasilając wówczas wszystkie cztery silniki trakcyjne. Układ biegowy lokomotywy nie uległ większym zmianom [5]

Budowa oraz rozmieszczenie maszyn i urządzeń lokomotywy typu 6Dk znacznie różni się od typu 6D. Zauważyć można, że niektóre elementy jak itd. 
prostownik trakcyjny są nowością $\mathrm{w}$ tego typu lokomotywach. Spowodowane jest to zastosowaniem nowszej prądnicy głównej synchronicznej o mocy 420 kVA. Pudło lokomotywy jest konstrukcją modułowa, co oznacza, że składa się $\mathrm{z}$ modułów głównych mających określone przeznaczenie. W taki sposób poszczególne zespoły lokomotywy są posegregowane i oddzielone od siebie, co przyśpiesza lokalizacje i wymianę uszkodzonych zespołów lub podzespołów. W pudle lokomotywy zainstalowano żaluzje służące do odprowadzenia ciepła z poszczególnych modułów (sekcji) lokomotywy. Oprócz tego w celu możliwości dokonania oględzin technicznych oraz napraw niewymagających zdjęcia kapotu, zamontowano drzwi do każdej sekcji lokomotywy. Zabudowano reflektory na czole lokomotywy.

Kabinę maszynisty wyposażono w dwa nowoczesne, ergonomiczne pulpity sterownicze posiadające te same funkcje. Pulpity są umiejscowione w sposób umożliwiający prowadzenie pojazdu przodem do kierunku jazdy. Na pulpicie sterowniczym znajdują się takie elementy jak: nastawnik kierunku, manipulator jazdy, manipulatory hamulca lokomotywy i zespołowego, ekran diagnostyczny oraz elementy sygnalizacyjne. Pozostałe elementy sterowania lokomotywą są umieszczone w panelu rozdzielni elektrycznej znajdującej się za fotelem maszynisty. Podłoga kabiny została pokryta wykładziną antypoślizgową. Wejście do kabiny maszynisty odbywa się za pomocą drzwi umieszczonych po obu stronach kabiny po przekątnej względem siebie. Poprzez zastosowanie nowej konstrukcji kabiny maszynisty, widoczność zarówno w kierunku jazdy jak i przeciwnym znacznie uległa poprawie. Poprawiono komfort pracy maszynisty $\mathrm{w}$ okresie letnim instalując klimatyzację [5]

\subsection{Modernizacja przez zakład „NEWAG Nowy Sącz”}

Modernizacja lokomotywy SM42 z fabrycznego typu $6 \mathrm{D}$ na $6 \mathrm{Dg}$ nie zmieniła przeznaczenia lokomotywy oraz układu osi. Modernizacji poddano część mechaniczna. Zmodernizowano ostoje lokomotywy oraz stworzono nową konstrukcje kabiny maszynisty oraz pudła. Kabina umiejscowiona jest na ostoi w podobnej odległości od czoła lokomotywy jak w przypadku typu 6D. W przedniej części pudła zabudowano agregat napędowy składający się z silnika spalinowego czterosuwowego typu C27 ACERT firmy Caterpillar zużywający mniej paliwa, a także prądnice główną prądu przemiennego AC o mocy $662 \mathrm{kVA}$. Układ napędowy lokomotywy posiada jeden agregat napędowy. W najbliżej znajdującej się czoła pojazdu sekcji znajduje sprężarka śrubowa, wyłącznik główny lokomotywy, transformator oraz wentylator silników trakcyjnych. Podobnie jak w przypadku lokomotywy typu 6Dk zachowano silniki trakcyjne prądu stałego DC, co w rezultacie zmusiło do zastosowania prostownika trakcyjnego. W tylnej części pojazdu, za kabiną maszynisty umiejscowiono przedział szaf elektrycznych oraz przedział tablicy pneumatycznej. Lokomotywa dzięki układom mikroprocesorowym posiada sterowanie sterownikiem modułowym oraz diagnostykę pokładową nadzorującą pracę maszyn i urządzeń. W porównaniu do lokomotywy typu $6 \mathrm{Dk}$ może wpisywać się w jeszcze mniejsze promienie łuków. Zmodyfikowano oraz zregenerowano ostoje lokomotywy w celu umożliwienia posadowienia nowej konstrukcji pudła oraz wykonania kanałów wentylacyjnych. Zabudowane zostały nowe urządzenia pociagowo - zderzne na czole pojazdu [6].

Pudło lokomotywy typu 6Dg składa się z dłuższego przedniego i krótszego tylnego przedziału maszynowego, pomiędzy którymi posadowiona jest nowoczesna konstrukcja kabiny maszynisty. Przedziały maszynowe podczas modernizacji zostały obniżone o około $300 \mathrm{~mm}$ co skutkuje poprawieniem widoczności z kabiny maszynisty. Dookoła przedziałów maszynowych umieszczone są pomosty z poręczami. Lokomotywa posiada nowe halogenowe reflektory oświetlenia i sygnalizacji, które są wmontowane w konstrukcje ostoi [4].

Kabinę maszynisty podobnie jak w przypadku lokomotywy typu 6Dk wyposażono w dwa ergonomiczne pulpity sterownicze, na których znajdują się urządzenia kontrolno-pomiarowe niezbędne do sterowania lokomotywą. Zamontowano również ekran diagnostyczny umożliwiający podgląd i nadzór pracy poszczególnych maszyn i urządzeń. Wnętrze kabiny wraz z pulpitami sterowniczymi wyłożone są niepalnymi panelami $z$ żywic poliestrowych. Drzwi wejściowe do kabiny zamontowano z obu stron w sposób dający możliwość wejścia tylko przez pomost lokomotywy. Zainstalowano klimatyzację dla poprawy komfortu pracy w okresie wysokich temperatur. Dodatkowo w celu zmniejszenia oddziaływań drgań na maszynistę, kabinę zawieszono na czterech elementach gumowo-metalowych. Oprócz tego zamontowano w kabinie ergonomiczne fotele maszynisty posiadające thumiki drgań. Siedzisko jest wyprofilowane wraz z oparciem i ma możliwość regulacji wysokości, kąta pochylenia i podłokietników. Nowoczesny fotel maszynisty obrazuje [3].

Wózki lokomotywy nie uległy zmianom podczas modernizacji. Zamontowano system smarowania obrzeży kół oraz układ przeciwpoślizgowy. Hamulec postojowy zastapiony został hamulcem sprężynowym [4].

2.3. Porównanie modernizacji lokomotywy serii SM42

W tabela 2.1 przedstawiono porównanie ważniejszych danych technicznych zmodernizowanych lokomotyw przez dwa niezależne zakłady naprawcze. Obie koncepcje modernizacji różnią się w konstrukcji pudła i kabiny maszynisty. Lokomotywy typu 6Dk sa 
innowacyjną myślą konstruktorską, która dotyczy zastosowania dwóch agregatów napędowych. Daje to możliwość dostosowania mocy lokomotywy do potrzeb przewozowych, a przez to zmniejszenie zużycia paliwa i negatywnego wpływu na środowisko. Lokomotywy typu 6Dg są modernizowane pod kątem poprawy ergonomii pracy maszynisty, przy jednoczesnym zwiększeniu mocy w stosunku do typu 6D [9].

Obydwie modernizacje łączy zastosowanie tablic pneumatycznych, nowych silników spalinowych, prądnic prądu przemiennego, sterowników mikroprocesorowych oraz pozostawienie układu biegowego $\mathrm{z}$ wersji 6D [9]. Wysokość lokomotyw po modernizacjach zwiększyła się o $108 \mathrm{~mm}$ w przypadku typu $6 \mathrm{Dk}$ i o $38 \mathrm{~mm}$ w lokomotywach typu $6 \mathrm{Dg}$. Masa służbowa po modernizacjach zmniejszyła się odpowiednio o $2 \mathrm{i}$ 4 tony. Największą moc silnika spalinowego posiada typ 6Dk. W stosunku do lokomotyw SM42 przed modernizacją moc silnika spalinowego w obu modernizacjach zwiększyła się o $218 \mathrm{~kW}$ dla lokomotywy 6Dk i $120 \mathrm{~kW}$ w przypadku modernizacji wykonanej w Nowym Sączu.

\section{HALAS ODDZIALUJĄCY NA CZLOWIEKA I JEGO WARTOŚCI DOPUSZCZALNE}

Hałas wpływa niekorzystnie na stan zdrowia ludzi. Występuje praktycznie wszędzie tam, gdzie pracuja jakiegokolwiek typu maszyny i środki transportu. Hałas może wpływać na człowieka w dwojaki sposób: na narząd słuchu oraz na pozostałe zmysły i narządy organizmu. Negatywne skutki oddziaływania hałasu na narząd słuchu można podzielić na [8] utratę słuchu wywołaną podniesieniem progu słyszalności przez długotrwałe oddziaływanie hałasu na poziomie równoważnego dźwięku $80 \mathrm{~dB}$, krótkie zaburzenia słyszalności spowodowane krótkotrwałymi ekspozycjami na hałas o szczytowej wartości dźwięku powyżej $130 \mathrm{~dB}$.

Konsekwencje ogólnego wpływu hałasu na organizm ludzki mogą powodować: zaburzenia funkcji fizjologicznych organizmu, skurcze mięśni pod wpływem nagłego wysokiego poziomu dźwięku. Prowadzić może to do nadpobudliwości organizmu, co przyczynia się do zmniejszenia koncentracji pracownika. Ponadto wyróżnić można kilka ważniejszych skutków oddziaływania hałasu przy określonej jego wartości [1]
: przy około $70 \mathrm{~dB}$ mogą występować wegetatywne, niekorzystne zmiany $\mathrm{w}$ organizmie, przy wartościach większych od $75 \mathrm{~dB}$ moga pojawiać się uszkodzenia organiczne takie jak np. nadciśnienie tętnicze, niewłaściwa praca żołądka itd., powyżej $90 \mathrm{~dB}$ może wystapić pogorszenie słyszalności lub ubytek słuchu, od $120 \mathrm{~dB}$ pojawia się niebezpieczeństwo utraty słuchu.

W celu ograniczenia hałasu w środowisku pracy stosuje się różnego typu zabiegi powodujące zmniejszenie jego wpływu na otoczenie np. minimalizacja [8] generowanego hałasu przez maszyny poprzez stosowanie nowych rozwiązań technicznych, poziomu hałasu przez jego thumienie na drodze oddziaływania maszyna-człowiek, czasu pracy pracownika w środowisku hałasu.

Hałas powoduje problemy w porozumiewaniu się osób. Zaburza zrozumiałość mowy ludzkiej, co na stanowisku pracy odgrywa ważną rolę w wykonywaniu zleconych obowiązków. Wartości poziomu równoważnego dźwięku, które określają możliwości porozumiewania się osób przedstawia się następująco [2]:

- od 0 do $30 \mathrm{~dB}$ jest możliwe porozumiewanie się szeptem,

- od 30 do $55 \mathrm{~dB}$ porozumienie się głosem normalnym,

- od 60 do $75 \mathrm{~dB}$ porozumienie się głosem podniesionym,

- od 80 do $95 \mathrm{~dB}$ bardzo utrudniona rozmowa,

- od 95 do $100 \mathrm{~dB}$ porozumienie się tylko krzykiem,

- powyżej $100 \mathrm{~dB}$ brak możliwości porozumienia się ustnego.

Dyrektywa 2003/10/WE Parlamentu Europejskiego i Rady z dnia 6 lutego 2003 r. w sprawie minimalnych wymagań w zakresie ochrony zdrowia i bezpieczeństwa dotyczących narażenia pracowników na ryzyko spowodowane czynnikami fizycznymi (hałasem) [7]. Dyrektywa dotyczy wartości dopuszczalnych hałasu w środowisku pracy i ma zapewnić pracownikom ochronę słuchu w miejscu pracy. Obejmuje w swojej treści wartości dopuszczalne, które przedsiębiorstwa są zobowiązane przestrzegać, a w przypadku ich przekroczenia minimalizować.

Tabela 1. Porównanie ważniejszych danych technicznych lokomotyw 6D, 6Dk i 6Dg [9]

\begin{tabular}{|c|c|c|c|}
\hline Dane & $6 \mathrm{D}$ & $6 \mathrm{Dk}$ & 6Dg \\
\hline Producent & Fablok & PESA/CZ Loko & NEWAG \\
\hline Długość & $14240 \mathrm{~mm}$ & $14240 \mathrm{~mm}$ & $14240 \mathrm{~mm}$ \\
\hline Wysokość & $4285 \mathrm{~mm}$ & $4393 \mathrm{~mm}$ & $4323 \mathrm{~mm}$ \\
\hline Moc silnika spalinowego & $588 \mathrm{~kW}$ & $2 \times 403 \mathrm{~kW}$ & $708 \mathrm{~kW}$ \\
\hline Przekładnia elektryczna & DC-DC & AC-DC & AC-DC \\
\hline Prędkość ciagła & $12,5 \mathrm{~km} / \mathrm{h}$ & $19 \mathrm{~km} / \mathrm{h}$ & $13,5 \mathrm{~km} / \mathrm{h}$ \\
\hline Masa służbowa lokomotywy & $74 \mathrm{t}$ & $72 \mathrm{t}$ & $70 \mathrm{t}$ \\
\hline Rodzaj hamulca & Oerlikon & Tablica pneumatyczna & Tablica pneumatyczna \\
\hline
\end{tabular}


Wartość dopuszczalna dziennego ( 8 - godzinnego) poziomu ekspozycji na hałas $(85 \mathrm{~dB})$ jest wartością, która umożliwia po dłuższym czasie występowanie chorób układu krążenia oraz może zaburzyć pracę organów układu pokarmowego. Zapewnia w ciagu dnia pracy brak ubytku słuchu, co z punktu widzenia ochrony zdrowia pracowników jest najważniejszym kryterium.

\section{METODYKA BADAŃ}

Badania przeprowadzono w oparciu o założenia eksperymentu biernego. Oznacza to, że mierzono wybrane parametry opisujące hałas bez ingerencji $\mathrm{w}$ strukturę badanych obiektów. Pomiary przeprowadzono na terenie lokomotywowni w Poznaniu. Wszystkie badane lokomotywy, były w stanie zdatności po przeglądzie kontrolnym.

Pomiary hałasu wykonano na postoju $\mathrm{z}$ włączonym silnikiem (silnikami) spalinowym. Przetwornik dźwięku umieszczono w środkowej części kabiny maszynisty na wysokości ucha operatora pojazdu. Czas pomiaru wynosił $20 \mathrm{~min}$.

Do wykonania pomiarów hałasu wykorzystano całkujący miernik poziomu dźwięku typu 2238 firmy Brüel\&Kjaer. Miernik posiada możliwość odczytu podczas pomiaru poziomu równoważnego oraz maksymalnego i minimalnego poziomu skutecznego dźwięku. Urządzenie umożliwia zapis zmierzonych parametrów w pamięci wewnętrznej. Analizy wyników pomiarów dokonano za pomocą dedykowanego oprogramowania Noise Explorer 7815.

\section{WYNIKI PRZEPROWADZONYCH BADAŃ}

Wyniki pomiarów równoważnego poziomu hałasu w lokomotywach serii SM42 typu 6D 6Dk oraz 6Dg zostały przedstawione w tabeli 2 .

$\mathrm{Z}$ otrzymanych danych wynika, że poziom hałasu w kabinie maszynisty lokomotywy typu 6D osiaga największą wartość w przypadku pojazdu o numerze 847. Hałas generowany jest nie tylko przez pracę silnika spalinowego, ale też przez drgania elementów w kabinie maszynisty (okna kabiny, elementy znajdujące się na pulpicie, drzwi wejściowe, drzwi od szafy niskiego napięcia itp.). Najmniejszy poziom hałasu emitowany jest w lokomotywie o numerze 957 , mimo iż posiada największy przebieg eksploatacyjny z pośród badanych pojazdów. Wynikać może to $\mathrm{z}$ dokładności wykonania przeglądów i napraw technicznych przez personel obsługujący pojazdy.
Analizując dane dotyczące hałasu w kabinach lokomotyw typu 6Dk można stwierdzić, że lokomotywa z numerem 1604 o najniższym przebiegu eksploatacyjnym generuje największy poziom hałasu. Istotną informacją jest częsty przestój lokomotywy na naprawach serwisowych, co może świadczyć o nieodpowiedniej regulacji prędkości obrotowej dwóch agregatów, poprzez uszkodzenie sterowników mikroprocesorowych nadzorujących i sterujących ich pracę. Skutkiem tego może być zwiększenie prędkości obrotowych biegu jałowego silników spalinowych, co przekłada się na zwiększenie poziomu dźwięku w kabinie maszynisty. Pozostałe badane pojazdy uzyskały wyniki zbliżone do siebie, co uwidacznia poziom hałasu w kabinach lokomotyw typu 6Dk. Wartości zmierzonych parametrów nie przekraczają wartości dopuszczalnych ujętych w dyrektywie oraz rozporządzeniu.

$\mathrm{Na}$ podstawie wyników pomiarów hałasu w kabinach lokomotyw typu 6Dg można stwierdzić, iż jego wartości kształtuja się podobnie we wszystkich badanych pojazdach tego typu. Najmniejsze wartości poziomu hałasu uzyskała lokomotywa o numerze 1266 oraz 1234. Największy poziom hałasu w kabinie maszynisty odnotowano w pojeździe o numerze 1262. Badane lokomotywy typu 6Dg charakteryzowały się najmniejszym rozrzutem między wartościami parametrów opisujących hałas na stanowisku pracy maszynisty, co może świadczyć o wysokim standardzie i dokładności wykonania modernizacji przez producenta.

Porównanie poziomu średnich parametrów hałasu w kabinie maszynisty między poszczególnymi typami lokomotyw serii SM42 przedstawiono na rys. 1.

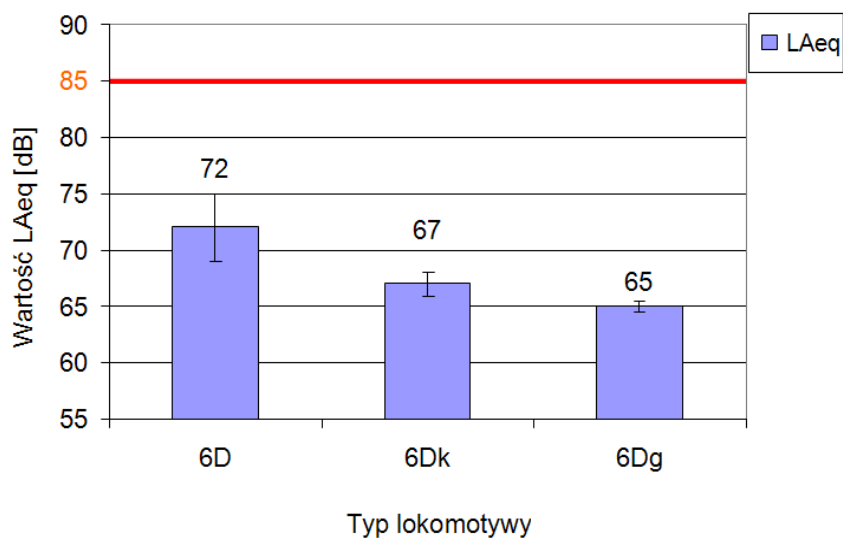

Rys. 1. Zestawienie średnich wartości poziomu równoważnego hałasu LAeq dla poszczególnych typów lokomotyw

Tabela 2. Wyniki pomiarów LAeq, dla lokomotyw typu 6D, 6Dk, 6Dg

\begin{tabular}{|c|c|c|c|c|c|}
\hline \multicolumn{2}{|c|}{ Lokomotywa SM42 typ 6D } & \multicolumn{2}{c|}{ Lokomotywa SM42 typ 6Dk } & \multicolumn{2}{c|}{ Lokomotywa SM42 typ 6Dg } \\
\hline \multirow{2}{*}{ Nr lokomotywy } & LAeq & Nr lokomotywy & LAeq & Nr lokomotywy & LAeq \\
\cline { 2 - 6 } & {$[\mathrm{dB}]$} & & {$[\mathrm{dB}]$} & & {$[\mathrm{dB}]$} \\
\hline 330 & 73 & 1602 & 66 & 1234 & 65 \\
\hline 847 & 75 & 1604 & 68 & 1262 & 66 \\
\hline 957 & 69 & 1605 & 66 & 1266 & 65 \\
\hline Wartość średnia & 72 & Wartość średnia & 67 & Wartość średnia & 65 \\
\hline Odchylenie standardowe & 3 & Odchylenie standardowe & 1,1 & Odchylenie standardowe & 0,5 \\
\hline
\end{tabular}


Analizując rysunek 1 można stwierdzić, że modernizacja lokomotyw serii SM42 ma wpływ na poziom hałasu oddziałującego na maszynistę. Poziom wartości równoważonego hałasu został obniżony poniżej $70 \mathrm{~dB}$. Spośród zmodernizowanych typów lokomotyw niższe poziomy parametrów hałasu uzyskano $\mathrm{w}$ pojazdach typu 6Dg. Niewiele większe wartości (większe o $2 \mathrm{~dB}$ ) zmierzono w lokomotywach typu 6Dk. Różnica pomiędzy wartościami parametrów lokomotywy przed i po modernizacji jest odczuwalna przez osoby znajdujące się na stanowisku maszynisty (badania ankietowe). Wartość dopuszczalna równoważnego poziomu hałasu $(85 \mathrm{~dB})$ określona przez dyrektywy i rozporządzenia nie została przekroczona w żadnej z badanych lokomotyw.

\section{PODSUMOWANIE}

Pomiary zostały przeprowadzone zgodnie $\mathrm{z}$ normami zawartymi $\mathrm{W}$ zamieszczonych $\mathrm{W}$ pracy dyrektywach i rozporządzeniach. Obiektami, które zostały poddane badaniom to lokomotywy eksploatowane przez Wielkopolski Zakład Spółki PKP CARGO w Poznaniu. Wyniki pomiarów obrazują poziomy i wartości czynników szkodliwych dla zdrowia człowieka pracujaccego w kabinie maszynisty. Wszystkie uzyskane rezultaty nie przekraczają wartości dopuszczalnych. Badania zostały przeprowadzone podczas postoju lokomotywy bez używania sygnałów dźwiękowych. W związku z tym nie jest znana emisja badanych, szkodliwych czynników podczas jazdy. Przeprowadzenie badań na większej ilość lokomotyw serii SM42 każdego typu pozwoliłoby uogólnić wnioski. $\mathrm{Na}$ podstawie dokonanych pomiarów i uzyskanych wyników uzyskuje się następujące wnioski dla badanych egzemplarzy: poziom równoważny hałasu LAeq zmniejszył się o 7 $\mathrm{dB}$ w przypadku modernizacji przez zakłady NEWAG $(6 \mathrm{Dg})$, efektem modernizacji lokomotyw $\mathrm{w}$ firmie PESA (6Dk) jest redukcja poziomu LAeq o $5 \mathrm{~dB}$.

\section{Bibliografia}

[1] Czeskin M. S. Człowiek i hałas, Warszawa 1986

[2] Engel Z., Ochrona środowiska przed drganiami $i$ hałasem, Wydawnictwo Nankowe PWN, Warszawa 2001.

[3] Koszyk P., Budowa lokomotywy 6Dg, NEWAG, Materiaty niepublikowane.

[4] Szewczyk Wiesław, Modernizacje lokomotywy SM42 wersja 6 Dg produkcji NEWAG Nowy Sacz - nowoczesność, ekologia i ekonomia. Technika Transportu Szynowego $\mathrm{nr}$ 4/2010.

[5] Dokumentacja systemu utrzymania, CZ LOKO Ceska Trebova, PESA Bydgoszcz S.A. Materiaty niepublikowane.

[6] Dokumentacja systemu utrzymania, NEWAG S.A. Materialy niepublikowane.

[7] Dyrektywa 2003/10/WE Parlamentu Europejskiego i Rady z dnia 6 lutego 2003 rw sprawie minimalnych wymagań w zakresie ochrony zdrowia i bezpieczeństwa dotyczqcych narażenia pracowników na ryzyko spowodowane czynnikami fizycznymi(hałasem)

[8] Strona internetowa: http://www.ciop.pl, dostęp: listopad 2012.

[9] Strona internetowa: http://inforail.pl, dostep: sierpień 2012. 